\title{
TEACHERS AS RESEARCHERS: THE PERCEPTIONS AND PRACTICES OF CANTHO TERTIARY EFL TEACHERS
}

\author{
Nguyen Thi Thu Uyen ${ }^{1}$ \\ Truong Vien ${ }^{2 i}$ \\ ${ }^{1} \mathrm{MA}$, Can Tho University, \\ Can Tho, Vietnam \\ ${ }^{2}$ Assoc. Prof. Dr.,
} Hue University of Foreign Languages, Hue, Vietnam

\begin{abstract}
:
This descriptive study aims to investigate tertiary EFL teachers' perceptions and practices of doing research. The study was conducted with the participation of 67 EFL teachers from tertiary institutions in Cantho of Vietnam. Quantitative and qualitative data were gathered via the questionnaire and semi-structured interviews to provide insights into how Cantho tertiary EFL teachers perceive the benefits and challenges of doing research as well as their current status of practices as researchers. The study revealed that (1) Cantho tertiary teachers held positive perceptions of conducting research in the field of English language teaching, and that (2) their practices as researchers were reported to be at a high level. Understanding these is an important part of the broader process of attempting to resolve research challenges teachers are facing and thus to encourage teacher research engagement among EFL teachers.
\end{abstract}

Keywords: teachers as researchers, perceptions, benefits, challenges, practices

\section{Introduction}

\subsection{Theoretical background}

Second language acquisition has been researched broadly from different angles in the past decades. However, there has still been a separation between general theories and practical values in the profession that needs tackling. Research in educational areas received public criticism since it did not arouse anybody's interests outside the academia and according to Hargreaves (1996, cited in Watkins, 2006), that the knowledge was not closely connected to practice causes the theory-practice gap. Rose $(2002 ; 44)$ also condemned that "there is a widening gulf between researchers and practitioners and research often fails to focus on the real life experience of most teachers".

${ }^{i}$ Correspondence: email thuuyen1212@gmail.com, truongviensp@gmail.com 
Gomm \& Hammersley (2002) used the phrase "two worlds" to indicate that researchers and teachers are from two distinct groups. While research is theory-based, teaching is more practice-based. Hargreaves (1996) claimed that the gap derives from teachers' perceptions that doing research is researchers' responsibility rather than teachers' as the theory-filled nature of research does not spark teachers' interests. According to Gall and Borg $(2007 ; 10)$ "...the knowledge base keeps going, but it does not necessarily mean that educational practitioners know about it, value it and apply it in their work".

The nature of research has still faced plenty of arguments. Nevertheless, contrary to those arguments, teachers are still believed to be encouraged to do research. Borg $(2007,2009,2010)$ claimed that teachers should get involved in doing educational research since research engagement enables them to reach more informed and evidence-based decisions based on their research findings, which, as a result, will benefit both teaching and learning (Hargreaves, 2001). Besides, teachers' research engagement is advantageous for their professional development (Borg 2010; McDonough, 2006). In other words, implementing research allows teachers to have superior understandings of their work, motivates them to do more reflections and come up with new ideas and end up being more autonomous (e.g., Kirkwood \& Christie, 2006; Tinker Sachs, 2000).

Stimulated by the idea of motivating teachers to be engaged in research, an emergent strand of research has concentrated on looking at teachers' current status of research practice and their perceptions of what drives and discourages teacher research (e.g., Allison \& Carey, 2007; Shehadeh \& Barkhuizen, 2009; Borg 2007, 2009).

\subsection{Contextual background}

Teaching English as a Foreign Language (TEFL) at tertiary level in Vietnam has become a paramount concern. For the sake of raising the quality of English teaching and learning in order to meet the increasing needs of training highly qualified talents of foreign languages at tertiary level, there are calls for TEFL tertiary teachers to conduct research for professional development. Stenhouse (1975 cited in Nunan, 1997) claimed that education can only improve when teachers are engaged in research and the best curriculum is the result of teacher researcher collaboration. English teachers need to "change their educational philosophy, substantiate and perfect their composition of knowledge in their own discipline and other trans disciplines, lift their comprehensive quality, breed their research awareness and strengthen their research consciousness" (Yang, Zhang, \& Xie, 2001). Therefore, research and academic qualifications become necessary in academics' work, especially when research has become high on universities' agenda (Fanghanel, 2012).

In the context of English Education in Cantho city of Vietnam, teachers' conducting research has not been strongly promoted. This study sheds light on why and why not tertiary teachers carry out research via findings about their perceptions of the benefits and challenges of research engagement as well as their current status of research practices. Understanding these plays an essential role in the broader process of lowering the barriers and encouraging teacher research engagement to make it a more feasible activity in English language teaching. This work substantially contributes to the English education in Cantho particularly and Vietnam in general. 


\subsection{Research questions}

In order to fulfil the aims of the study, the following two research questions are raised:

1) What are the perceptions of doing research by Cantho's tertiary EFL teachers?

2) What are the practices of doing research by Cantho's tertiary EFL teachers?

\section{Literature review}

\subsection{Teachers as researchers}

Teachers are conventionally considered as consumers rather than producers of research. Researchers generate knowledge while teachers consume it by putting it into their school and classroom practice. Kutlay (2013) claimed that teachers are seen as the practitioners and the implementers of research findings published by researchers. Practitioners and researchers belong to two different groups since they do very different jobs. A big disparity between researchers and practitioners causes a problem about how to bridge the gap between the practitioners and researchers (Robinson, 1993). Very quickly, such differences lead to polarity and opposition. On some occasions, researchers are thought by practitioners to be imperious, ready to criticize and introduce changes, without taking the complication of the contexts they are researching into account (Hammersley, 2000). On the contrary, practitioners are viewed to be defensive and unresponsive, lacking understanding of the intellectual and practical challenges arising from carrying out useful school and classroom-based research.

This view has been challenged lately because teachers are considered as researchers as well as practitioners of educational research (Kutlay, 2013). Stenhouse (1981) stated that teachers cannot depend on theory without testing it in their own classrooms because the findings of education research are context bound and cannot be applied directly in every classroom. According to Carr and Kemmis (1986), the 'teacheras-researcher' movement can be seen as a response to the political climate. Teachers' role had been conformers, mere technicians implementing the curriculum, attempting to accomplish the objectives decided from researchers, outside the domain of their management. Teachers as researchers are supposed to have their own authorities to control their teaching situation again, and give professional assessments based on their expertise and experience and the essential needs of practical situations.

Cochran-Smith and Lytle (1990) suggested that the concept of teacher as researcher can interrupt conventional views about the relationships of theory and practice and the roles of teachers in educational change, bridging the gap between teachers and researchers, knowers and doers, and experts and novices. It also relates teaching and curriculum to broader political and social issues.

Stenhouse $(1981,104)$ asserted that 'It is teachers who in the end will change the world of the school by understanding it'. He supposed that teachers should be active meaning-makers in their own classroom practice by identifying their concerned issues, exploring them on their own so that they can understand and solve their problems related to pedagogy and curriculum. Such a movement was constructed by a view of the teacher as a knowledge generator rather than a recipient of theories proposed elsewhere and a 
view of the teacher in the classroom as a partner with the teacher in the academy (Stenhouse, 1983).

\subsection{Teachers' perceptions of doing research}

Although language teachers' perceptions and values about research can undoubtedly affect their approaches to classroom practices and support teachers to adopt a research orientation toward teaching, few literatures are found in this regard both in education generally and in the area of language teaching. McDonough (2006) believed that teachers do not see conducting research as one of their principal duties although they can reap great benefits from doing it in their classrooms. Similarly, Crookes (1993) claimed that in language teachers' perceptions, most research articles are not directly related to immediate classroom situations and needs. Research is also considered by most teachers as an activity conducted by "experts" and in particular conditions like laboratories. Markee (1997) also suggested that many language teachers think research articles use too technical language and therefore worthless for them.

Besides, according to Kutlay (2013), teachers held a belief that research is suitable for doing science rather than for practice. They believe that one study cannot be applicable in every context, and it does not have to do so. This belief contradicts the findings (Brown, 1988; Seliger \& Shohamy, 1989) which confirmed that research studies should be generalizable from one context to another. Additionally, the study conducted by Kutlay (2013) also found that teachers did not really place trust in the impacts that research brought to their classroom practices.

For many teachers, research seems to be an irrelevant and unfeasible activity (Borg, 2009). Jungck (2001, as cited in McDonough, 2006) asserted that in teachers' perceptions, implementing research involves some positivistic issues such as validity, reliability, generalizability, scaling, and statistics. Kutlay (2013) added teachers' perceptions of research are shaped by the scientific concepts including examining hypotheses, collecting large samples and statistics, analyzing data, and objectivity of the researcher. Together with their uncertainty about the importance of dissemination of research results, teachers often give up doing research they start due to the challenges.

As Burns (1999) maintained, in order to develop education at any level, teaching needs to be improved. Language teachers play a pivotal role in language education and learning. What they know and believe about issues related to their professional practices.

\subsection{The importance of doing research to teachers}

There are considerable benefits teachers can obtain when they conduct research (Goswami \& Stillman 1987; Kemmis \& McTaggart 1988; Elliott \& Sarland 1995; Burns 1999; Henson 2001; Kincheloe 2003; Olson, 1990). For example, Olson (1990) states that such engagement "improves teachers' instructional decision-making processes . . . helps empower teachers to influence their own profession... [and] offers the overriding and ultimate advantage of providing the potential for improving the educational process" (pp. 17-18). This is then shared by Hargreaves (2001) that engaging with and in research and making 
pedagogical decisions based on strong research evidence will be beneficial for both teaching and learning.

Bughio (2015) held the view that teachers who actively get involved in doing research at their school could study, evaluate, and assess their teaching pedagogies and practices. When teachers scrutinize their teaching practices, and are able to find out the problems of their classrooms and their students, reflect on them, then handle them, they will become confident and independent to tackle their school issues by themselves. Besides, identifying what went wrong and what went well in classroom teaching and learning helps teachers to determine the appropriate kinds of teaching styles and methods for their learners (Hine, 2013). This raises their awareness and understanding of their students (Borg, 2014; Hong \& Lawrence, 2011; Burns, 2010), and allows them to change and enhance their teaching methodologies, which significantly affects students' learning and success.

Watkins (2006) added teachers conducted research for their own professional development since it enabled them to observe the teaching practice from an outsider's angle, accumulate techniques from other teachers, or share with other educators (GrimaFarrell, 2017) and apply research findings into their own classroom practice and establish social networking as well. McNiff (2010) also agreed that research benefits teachers' professional development as firstly it examines whether the teaching practice meets the intended outcome of ones' work; secondly, it helps make evaluations of teaching pedagogies that need changing or improving and lastly, it puts a value on one's work and profession. The suggestion that teachers should carry out research has also been based on arguments about the benefits doing research brings for teachers in terms of professional development (see, for example, Kincheloe, 2003; Lankshear and Knobel, 2004; Kirkwood and Christie, 2006) and, from a critical perspective, for their status as professionals:

“...teachers need to be encouraged to move out of their submissive position and to take a much more innovatory, as opposed to implementary, role in curriculum development. One way to do this is to adopt the perspective of the researcher." (Gurney 1989: 15)

Furthermore, "research-active teachers develop a sense of agency in their working lives, taking an active role in managing their learning, organizing their work environments, and making changes to school communities, curricula, and their classroom practices" (Everton, Galton, \& Pell, 2000; Shkedi, 1998).

Another benefit of conducting research is that on a professional level, it can increase professional status, including being useful for promotion (Yang et al., 2001). Moreover, teacher research strengthens the position of teaching in the society and provides useful teaching and learning materials to their colleagues, policy makers, academic researchers, and teacher educators (Francis, Hirsch, and Rowland, 1994).

In English language teaching context, doing research allows TEFL academics to reflect and develop their teaching (Borg, 2007, 2009), and provide them with the latest TEFL theories and practices (Borg, 2009). Additionally, on a personal level, conducting 
research can satisfy academics "curiosity and creativity" (Chen, Gupta, \& Hoshower, 2006). Those who make an impact in a wider arena such as conference presentations, publications or participating in project work may also create chances for impacting and informing policy making (Brindley, 1991).

\subsection{How do EFL teachers do research?}

In EFL contexts, teachers are passive or even not involved in designing curriculum, developing materials, procedures of selection and evaluation (Troudi \& Riley, 1996). These duties are considered as experts' or researchers' in the field. This results from the gap between theory and practice. However, recently, there has been a growing interest in TESOL teachers' research engagement, teachers do not play a role of an implementer of theories developed by other researchers. Instead, they become explorers (Kumaravadivelu, 2006) who can produce their own theories based on their own classroom context, students, objectives and socio-cultural environment (Kumaravadivelu, 2001). When teachers themselves have the capacity to design, change the curriculum and its content to make learning more manageable for learners. As Richards and Renandya (2002, p. 358) state, "it is what teachers think and do at the classroom level that eventually determines what learners learn in the classroom."

On the other hand, a previous study (Xu, 2013) investigating the status of research practice by Chinese tertiary through narrative frame and in-depth interview questions showed that EFL teacher research engagement derives from extrinsic motivation, along with passive and powerless attitudes towards research. This can be explained that teachers are under pressure from educational administration or policy which appreciates research over teaching and other responsibilities (Kelchtermans, 2011). Teachers seem to have no choice but become research- engaged and research, therefore, is not teachers' daily practice. This phenomenon is going against the essence and values of teacher research which aims to improve teaching and learning. Furthermore, the findings showed that teachers' low level of research practice is attributed to some barriers such as heavy workloads at school, inaccessibility to resources, inadequacy in support or selfefficacy beliefs. The results further indicated that the university EFL teachers prefer reading research to doing research.

\subsection{Challenges of doing research}

When conducting research studies, teachers inevitably face some challenges. The studies by Cain and Milovic (2010); Ellis and Loughland (2016); Kutlay (2013); Norasmah and Chia (2016); Vásquez (2017); and Zhou (2012) indicated common problems that a teacher often encountered when doing research.

Firstly, insufficient time was a frequently-cited challenge in research studies conducted by academics from higher education in general and in TEFL (e.g., Borg, 2007, 2009; Brocato \& Mavis, 2005; Gao, 2006; Grbich, 1999; Hemmings et al., 2007; Hiep, 2006). In fact, teachers need to balance their work and their personal life, for example, a quality time both for conducting research and for their families (Vásquez, 2017). Besides, according to Allison and Carey (2007), teachers' explanation for their lack of time is that 
their priority is to meet students' immediate classroom needs, which consumes their great amount of time and energy, so they have no time left for conducting research or carrying out a project.

Furthermore, Allison and Carey (2007: 70) also listed lack of encouragement and motivation to do research and teachers' limited expertise and skills in the area of research as challenges by surveying the views of EFL teachers at a Canadian university. This is similar to the conclusion reached by Borg (2006b, 2007a, b, c, 2009a) who examined teachers' conceptions of research through a series of studies participated by over 2,900 language teaching professionals all over the world. For instance, Borg (2009a) with research studies with over 500 teachers in 13 countries stated that limited knowledge, skills and attitudes together with unsupportive institutional conditions accounted for the fact that reading and doing research are infeasible and undesirable activities. This suggestion is also shared by Dornyei (2007) proposing that teachers do not carry out research in their classes due to time limitation, incentives, and professional expertise in the area of research.

A research conducted by Biruk (2013) in Ethiopia proposed that not many teachers implemented research owing to the inadequate sources of reference materials, lack of research training programs for teachers to improve their research knowledge and skills. research studies in the ASEAN context about challenges teachers - researchers conducted recently by Norasmah and Chia (2016) in Malaysia; and Ellis and Loughland (2016) in Singapore and NSW showed the same findings.

Another source of challenge hindering teachers from implementing research relies on their beliefs (David, 2002, p. 12). Teachers normally consider doing research as researchers' responsibility rather than a way to raise their quality of teaching and learning as well as handle educational problems.

Finally, Ulla (2018) mentioned lack of financial incentives as another challenge in his most recent study about teachers' challenges of doing research in Philippine public schools. Teacher-researchers said that they did not receive financial incentives for their research contribution. This acted as a deterrent to teachers' research engagement.

\subsection{Related studies}

Although an interest in teacher research engagement is also evident in the literature on English language teaching (ELT), in this area only a few empirical studies were conducted about teachers' conceptions of research. These studies are reviewed below.

An empirical research in English language teachers' engagement in research was carried out by Allison and Carey (2007) recently with 22 participants who were English teachers at a university language center in Canada. Their views about research were gathered through questionnaires and interviews. The study results showed that teachers did not have enough time to balance both their teaching duties and doing research; besides, they are not encouraged and motivated enough to do research since it is not described as a requirement in their teaching job at school.

Borg (2009) conducted a mixed-methods research investigating the conceptions of doing research. Participating in the research were 505 English teachers from 13 countries 
in Europe, Asia, Africa, the Middle East, and Australia. Data were collected through questionnaire and follow-up interview instruments focusing on EFL teachers' conceptions about research, their beliefs about the characteristics of good research, receptions of the research culture in their institutions, engagement with (reading research) and in research (doing research), as well as their personal background information. According to Borg's (2009) study, teachers' practices of reading about and doing research were at moderate to low levels. Besides, shortage of time, research knowledge, and inaccessibility to research documents were counted as research challenges.

In a study of TEFL (Teaching English as a Foreign Language) education research culture in Vietnamese universities, Hiep's (2006) explored the research culture of tertiary EFL teachers in Vietnam. Data collected from official documents and interviews with 9 participants presented the results that although Vietnamese English language educators agreed on the necessity of conducting research in English language education, they were discouraged to do research because of some factors namely inadequate time, lack of access to reference materials and opportunities to circulate findings, and contextually inappropriate training, ongoing evaluation regulations, conventions and formats in reporting research results.

This review of the literature suggests that in comparison to the volume of empirical work which has been conducted into teachers' research engagement in education generally, little research into this area has been conducted in the field of English language teaching (ELT) at tertiary level and in a particular context of Vietnam. The study I presented here aimed to do this with data gathered from EFL teachers at Cantho's tertiary educational institutions of Vietnam and hopefully to fill the research gap.

\section{Methodology}

\subsection{Participants}

\subsubsection{Participants for the questionnaires}

67 EFL teachers from universities and colleges in Cantho were selected to take part in this study on the basis of convenient sampling technique (Fraenkel, Wallen, \& Hyun, 2012). Specific information of the research population is summarized as below:

Table 3.1: Percentage of participants' gender, age and workplace

\begin{tabular}{|l|c|c|c|c|c|c|c|c|}
\hline Variables & \multicolumn{2}{|c|}{ Gender } & \multicolumn{4}{c|}{ Age } & \multicolumn{3}{c|}{ Workplace } \\
\hline & Male & Female & $\mathbf{2 5 - 3 5}$ & $\mathbf{3 6 - 4 5}$ & $\mathbf{4 6 - 5 5}$ & $\mathbf{5 6 - 6 5}$ & College & University \\
\hline $\mathrm{N}$ & 21 & 46 & 31 & 23 & 12 & 1 & 31 & 36 \\
$(\%)$ & $(31.34)$ & $(68.66)$ & $(46.27)$ & $(34.33)$ & $(17.91)$ & $(1.49)$ & $(46.27)$ & $(53.73)$ \\
\hline
\end{tabular}

Total: $\mathrm{N}=67(100 \%)$ 


\begin{tabular}{|c|c|c|c|c|c|c|c|}
\hline \multirow{2}{*}{ Variables } & \multicolumn{4}{|c|}{ Years of experience } & \multicolumn{3}{|c|}{ Qualifications } \\
\hline & Under 10 & $11-20$ & $21-30$ & $31-40$ & Bachelor & & Doctorate \\
\hline $\begin{array}{l}\mathrm{N} \\
(\%)\end{array}$ & $\begin{array}{c}25 \\
(37.31)\end{array}$ & $\begin{array}{c}25 \\
(37.31)\end{array}$ & $\begin{array}{c}12 \\
(17.91)\end{array}$ & $\begin{array}{c}5 \\
(7.46)\end{array}$ & $\begin{array}{c}7 \\
(10.45)\end{array}$ & $\begin{array}{c}50 \\
(74.63)\end{array}$ & $\begin{array}{c}10 \\
(14.93)\end{array}$ \\
\hline
\end{tabular}

\subsubsection{Participants for the semi- structured interviews}

The selection of interviewees for interviews followed purposeful sampling (Creswell, 2008), so that variations in teaching and research experience, qualifications, research areas and research productivity could be represented. The interviews were conducted with 6 English teachers at the age of 26 to 50 equally distributed to each type of institution. They include 3 participants from universities and 3 participants from colleges.

\subsection{Instruments}

Two main instruments were employed in this study. The questionnaire was used to gather data about EFL teachers' perceptions of research engagement and their practices as researchers, while semi-structured interviews were conducted for in-depth investigation of their ideas, attitudes, perception, etc.

The questionnaire adapted from Borg (2010) was used to examine teachers' perceptions of the benefits and challenges of carrying out research, and from Rahimi (2018) about teachers' practices as researchers. Some items were modified under the guidance of my supervisor to suit the purposes of the study.

The interview was designed based on the research questions and the responses to the questionnaire. The interview consisted of 3 clusters with 6 questions focusing on (1) tertiary EFL teachers' perceptions of the benefits of doing research, (2) tertiary EFL teachers' perceptions of the challenges of doing research and (3) tertiary EFL teachers' practices as researchers.

\subsection{Procedures}

The data collection was conducted within 14 weeks, including 7 main steps. In the first two weeks, the questionnaires and interview questions were designed after the consultations with the supervisor. In the third week, the questionnaires were piloted with 32 tertiary EFL teachers to ensure that the questions were reliable enough to be used for the study.

In the next two weeks, the questionnaires were delivered officially to 67 tertiary EFL teachers. After collecting the data from the delivered questionnaire, these data were synthesized for the study in the sixth and seventh week.

In the eighth and ninth week, the researcher conducted semi-structured interviews to get in-depth information about teachers' perceptions of research implementation and their practices as researchers. In the tenth and eleventh week, the in-depth information coming from semi-structured interviews was synthesized for the analysing process which was conducted in the last three weeks of the study. 


\section{Results and Discussion}

\subsection{Results}

\subsubsection{Tertiary EFL teachers' perceptions of conducting research}

\section{A. Findings from the questionnaire}

\section{a. Tertiary EFL teachers' perceptions of the benefits of conducting research}

Section Two of the questionnaire consists of 16 items that correspond to EFL teachers' perceptions of the benefits of conducting research.

A Descriptive Statistics Test was carried out to determine the mean scores of four clusters namely Teaching and professional development, Learners and learning, Political issues, Economic issues. Table 4.1 below presents the results of the test.

Table 4.1: The mean scores of four clusters of tertiary EFL teachers' perceptions of the benefits

\begin{tabular}{llllll}
\hline & $\mathbf{N}$ & $\mathbf{M i n}$ & $\mathbf{M a x}$ & $\mathbf{M}$ & SD \\
\hline Teaching and professional development & 67 & 2.13 & 5.00 & 4.29 & .53 \\
\hline Learners and learning & 67 & 1.00 & 5.00 & 3.59 & .79 \\
\hline Political issues & 67 & 2.33 & 5.00 & 4.16 & .64 \\
\hline Economic issues & 67 & 1.00 & 5.00 & 3.73 & 1.02 \\
\hline
\end{tabular}

Table 4.1 shows that the mean scores of Teaching and professional development $(\mathrm{M}=$ $4.29, \mathrm{SD}=.53)$ and Political issues $(\mathrm{M}=4.16, \mathrm{SD}=.64)$ were at a higher level. The two clusters under the mean score of 4.0 were Learners and learning $(\mathrm{M}=3.59, \mathrm{SD}=.79)$ and Economic issues $(\mathrm{M}=3.73, \mathrm{SD}=1.02)$.

A One-way Anova Test was computed to examine the differences in tertiary EFL teachers' perceptions of the benefits of carrying out research by experience, qualification, workplace and gender.

The result showed that there was no significant difference in tertiary EFL teachers' perceptions of the benefits of doing research by qualification, workplace and gender. However, tertiary EFL teachers' perceptions of the benefits was significantly different by experience $(p=.023<.05)$. To be more specific, those who have been teaching from 11 years to 20 years and over 30 years expressed their strong agreement on the benefits (M $>4.20$ ) while teachers teaching from 21 years to 30 years and under 10 years were proved to agree with the benefits $(\mathrm{M}>3.8)$, as shown in Figure 4.1. 
Figure 4.1: Reported mean scores of perceptions of the benefits by experience

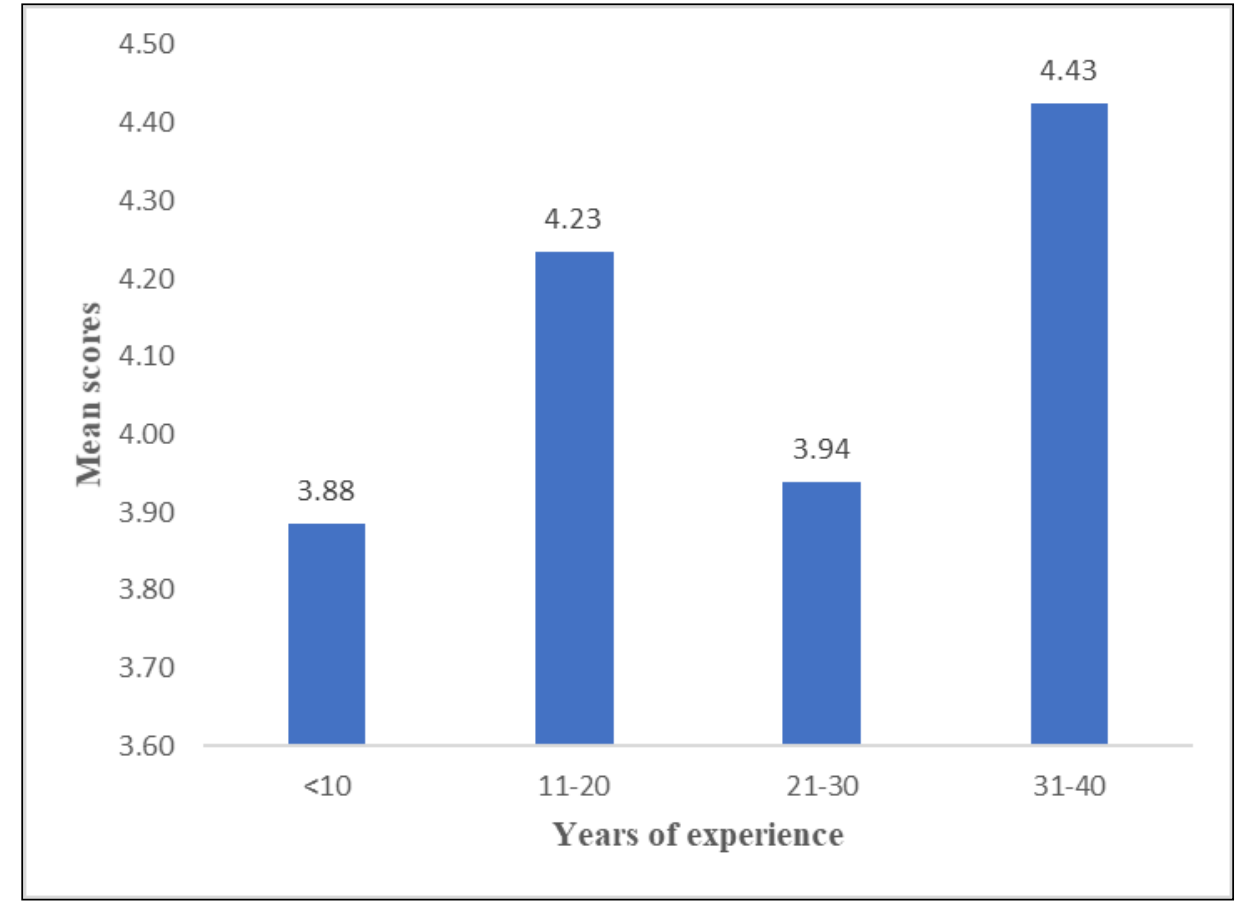

\section{b. Tertiary EFL teachers' perceptions of the challenges of conducting research}

Section 4 of the questionnaire consists of 19 items that correspond to tertiary EFL teachers' perceptions of the challenges of conducting research.

A Descriptive Test was computed to examine the mean scores of six clusters including students and colleagues' collaboration, teachers' awareness and skills, limited resources, demotivators, economic matters, leadership attributes. The results are shown in Table 4.2.

Table 4.2: The mean scores of six clusters of perceptions of the challenges teachers face when carrying out research

\begin{tabular}{llllll}
\hline & N & Min & Max & M & SD \\
\hline Students and colleagues collaboration & 67 & 1.00 & 5.00 & 2.58 & .88 \\
\hline Teachers' awareness and skills & 67 & 1.00 & 5.00 & 2.49 & .74 \\
\hline Resources & 67 & 1.75 & 5.00 & 3.05 & .72 \\
\hline Demotivators & 67 & 1.00 & 5.00 & 2.44 & .73 \\
\hline Economic matters & 67 & 1.00 & 5.00 & 3.04 & .83 \\
\hline Leadership attributes & 67 & 1.00 & 5.00 & 2.18 & .79 \\
\hline
\end{tabular}

As can be seen from the table, the mean scores of resources and economic matters $(\mathrm{M}=$ 3.05, $\mathrm{M}=3.04$ respectively) indicate that the participants had neutral views on the challenges of limited resources and economic matters. In addition, they expressed their disagreement on clusters of students and colleagues' collaboration, teachers' awareness and skills, demotivators, leadership attributes, which can be observed by the low mean scores $(\mathrm{M}<2.60)$. 


\section{B. Findings from the interviews}

\section{a. Tertiary EFL teachers' perceptions of the benefits of conducting research}

The interviews were conducted with 6 teachers in order to collect more data and gain insight into teachers' perceptions of doing research and their practices as researchers. The interview consisted of 3 clusters: (1) teachers' perceptions of the benefits of doing research; (2) teachers' perceptions of the challenges of doing research; (3) teachers' practices as researchers.

\section{- Improving teaching quality}

Three participants shared the same thought that conducting research enabled teachers to improve the quality of teaching. They said:

"...it somehow helps to improve teaching and learning quality and helps me understand the essence of the matter better." (Participant 1, lines 60-61, Interview extract)

"It helps me have better attitudes towards the method and apply it into my classroom practice to improve teaching and learning" (Participant 2, lines 121-123, Interview extract)

"I accumulate lots of knowledge and experience from previous educators to improve my teaching." (Participant 6, lines 322-323, Interview extract)

\section{- Broadening teachers' horizons}

Some others suggested that doing research enhanced teachers' knowledge. Their views were illustrated as the following comments below:

"It broadens my horizons since when I do research, I search for a lot of reference materials" (Participant 3, lines 172-173, Interview extract)

"Doing research allows teachers to understand the theories of teaching methods better and know more about previous related studies" (Participant 4, lines 220-122, Interview extract)

"I accumulate lots of knowledge and experience from previous educators to improve my teaching." (Participant 6, lines 322-323, Interview extract)

\section{- Improving students' learning}

Another benefit mentioned was that doing research enhanced students' learning.

"It helps me have better attitudes towards the method and apply it into my classroom practice to improve teaching and learning" (Participant 2, lines 121-123, Interview extract) 
"Based on the research findings, I can help improve my students' learning efficiency and understand them better." (Participant 5, lines 271-271, Interview extract)

"Doing research allows teachers to understand the theories of teaching methods better, know more about previous related studies and understand my students thoroughly." (Participant 4, lines 220 - 222, Interview extract)

\section{- Improving professional status and contributing to the school's achievement}

Besides, some participants considered promotion opportunities, contribution to the success of the institutions in general and materials sources for other researchers as benefits of doing research.

"My efforts are recognized and I can get higher qualifications to get a promotion." (Participant 1, lines 61 -62, Interview extract)

"Besides, it contributes to the achievements of the school in general. Also, it provides materials for other researchers." (Participant 3, lines 173-175, Interview extract)

\section{b. Tertiary EFL teachers' perceptions of the challenges of conducting research}

The interviewees were asked about the challenges of doing research. The findings showed that participants held different views on research challenges.

\section{- Lack of time}

Participant 1, on the other hand, suggested the difficulty in time management. Participant 1 said:

"I do my full-time job during the daytime and in the evening, I do an extra job in foreign language centers. So, it's hard for me to have enough time to search and read references materials" (Participant 1, lines 64 - 66, Interview extract)

\section{- Limited research knowledge and skills}

Participants 1 and 2 agreed that identifying a research topic was difficult. These responses were commented below:

"To me, the hardest thing is identifying the research topic, questions, methods and instruments which can answer the research questions" (Participant 2, lines 125 -126, Interview extract)

"As for me, the most difficult thing is looking for a new topic to do research into." (Participant 3, lines 177, Interview extract)

Participant 2 had trouble with designing the instruments. 
"The challenges of doing research lie in identifying research topics, research questions and especially, designing research instruments which can answer the research questions." (Participant 2, lines 125 - 127, Interview extract)

Participant 5 shared another view of the difficulty in doing research related to data collection.

"It's challenging to collect data. Not everyone agrees to be interviewed and share reliable information." (Participant 5, lines 275 - 276, Interview extract)

One participant struggled with using software SPSS to analyze data.

"The challenge I have is how to analyze data. I mean how to run the software SPSS. It's hard for me. You know, I don't have good computer literacy. I have to ask my colleagues for help." (Participant 6, lines 325 - 327, Interview extract)

\section{- Inaccessibility to materials}

Participant 3 mentioned inaccessibility to reliable sources of information as a challenge.

"The second challenge I faced when researching was having access to reliable sources of information" (Participant 3, lines 177 -178, Interview extract)

\section{- Unexpected external factors}

Participant 4's challenge was unexpected external factors slowing down the research process:

"There are external factors preventing me from expediting my research. I am not able to keep my research process under control. For example, my data collection is affected because of Covid pandemic this year." (Participant 4, lines 226 - 228, Interview extract)

\subsubsection{Tertiary EFL teachers' practices as researchers}

\section{A. Findings from the questionnaire}

Section Three of the questionnaire consists of 20 items that correspond to tertiary EFL teachers' practices as researchers.

A Descriptive Statistics Test was run to measure the level of teachers' practices as researchers. The results of the test are displayed in Table 4.3.

Table 4.3: The mean score of tertiary EFL teachers' practices as researchers

\begin{tabular}{lccccc}
\hline Descriptive Statistics & \multicolumn{7}{c}{} \\
\hline & $\mathbf{N}$ & Minimum & Maximum & Mean & SD \\
\hline Teachers' practices & 67 & 1.75 & 4.95 & 3.8134 & .60993 \\
\hline
\end{tabular}


As can be seen from table 4.3 , the mean score of teachers' practices as researchers $(\mathrm{M}=$ $3.81, \mathrm{SD}=.61$ ) was at a high level. This result illustrates the point that tertiary EFL teachers' level of practice was relatively high.

As can be seen from Table 4.3, the mean score of procedures of conducting research was the highest $(\mathrm{M}=4.04)$ while that of frequency of conducting research was the lowest $(\mathrm{M}=3.24)$.

A One-way Anova Test was conducted to examine the differences in tertiary EFL teachers' practices as researchers by experience, qualification, workplace and gender.

The result showed that no difference was observed in teachers' practices as researchers by experience, workplace and gender. Nevertheless, there was a difference in teachers' practices as researchers by qualification $(p=.025<.05)$. Particularly, the mean score of research practices of teachers at Doctorate level $(\mathrm{M}=4.3)$ is significantly higher than that of those at Bachelor and Master level $(\mathrm{M}=3.5, \mathrm{M}=3.7$ respectively). This means teachers at Doctorate have a higher level of practice than those at Bachelor and Master level, as shown in table 4.27.

Table 4.27: Reported mean scores of teachers' practices as researchers by qualification

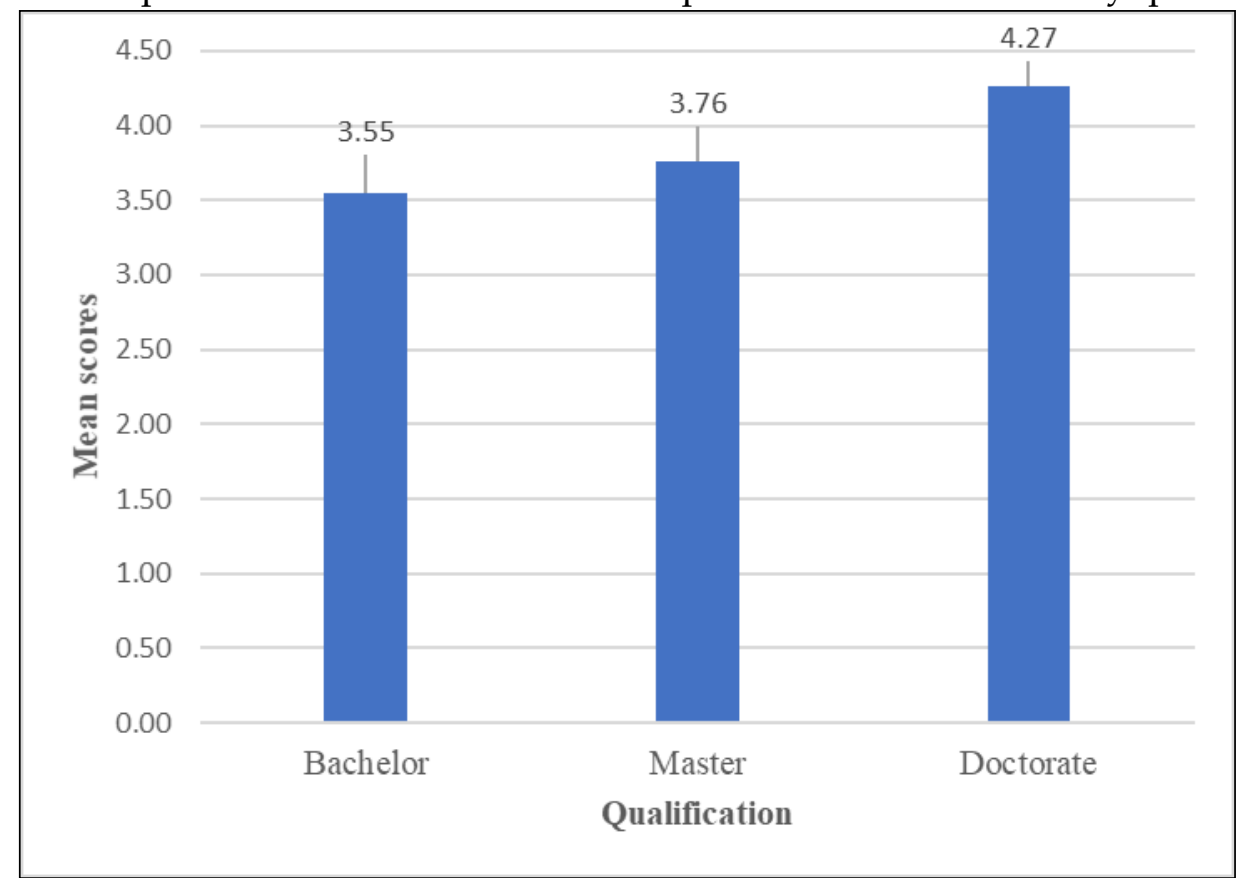

\section{B. Findings from the interviews}

\section{- Frequency}

When being asked about their frequency of conducting research, four participants said that they did not do research frequently.

"Honestly speaking, no" (Participant 1, lines 15, Interview extract) 
"I don't usually conduct research." (Participant 2, lines 95, Participant 3, lines 148, Interview extract)

"No. I don't have enough time to do research" (Participant 6, lines 298, Interview extract)

Two participants, on the other hand, do research regularly.

"Of course. I frequently conduct research." "I do research once a year." (Participant 4, lines 200, Interview extract)

"Yes. I conduct research on a regular basis." "About once a year" (Participant 5, lines 253, Interview extract)

\section{- Types of research}

In terms of research types, six participants shared they often conducted empirical research.

However, one participant often conducted neither empirical nor action research, but wrote reports or reflections.

"The only big research I conducted was the one in my Master program. Since then, I haven't done any research, but write reports of my own teaching experience or experience synthesized from previous studies." (Participant 6, lines 308 - 311, Interview extract)

\section{- Themes}

Regarding research themes, all of the participants focused on the area of teaching methods. For example:

"Topics arousing my interest are related to teaching skills for exams such as Speaking, Listening, Writing, Reading in IELTS, VSTEP, TOEIC" (Participant 1, lines 27 - 29, Interview extract)

"I'm interested in the topics about teaching methods especially technology application in English language teaching" (Participant 4, lines 209 -210, Interview extract)

One participant conducted research on learners' matters in studying research.

"I conduct research about students' learning matters such as their difficulties or their preferences in studying English" (Participant 5, lines 255 -257, Interview extract)

\section{- Procedures}

The interviewer asked the teachers to describe the steps they conducted in action research. All of the participants shared a similar way to conduct research, including 
reading reference materials to identify the research topic, determining the research purposes, research questions, research methods and designing research instruments, then collecting and analyzing data, reaching a conclusion and writing reports. For example:

"First of all, I read reference materials, previous studies to look for a suitable topic. Then, I identify research aims, questions and methods. Next, I write a proposal and ask for my supervisor's feedback on it. After that, I start to write Introduction, research aims, questions and Literature. To write this part, I have to read a lot of references, articles or previous studies. Subsequently, I design research instruments. I ask for my supervisor's feedback again and pilot. Then, I deliver them to participants and collect data. After analyzing the data, I complete chapter 3,4 and 5" (Participant 1, lines 44 -56, Interview extract)

"I read a lot of reference materials of other researchers, then identify the topic I find interest in and ask for my supervisor's advice. Next, I will write Intro, Literature. After that, I design research instruments and collect data. Finally, I analyze the data and write my report." (Participant 2, lines 112 -116, Interview extract)

"First, I look for a research topic. Then I read related reference materials. After that, I look for an experienced colleague to guide me and help me with my research topic, aims and questions, methods and instruments. Then I write a research proposal. Next, I design the instruments and collect data. Finally, I analyze the data, reach a conclusion and write my report." (Participant 3, lines 165 - 169, Interview extract)

Participant 6 also added the procedures she followed to write reports of teaching experience which is more simple, including less steps.

"...First, I find the topic I want to research into, look for related materials, read and synthesize the related or typical ones." (Participant 6, lines 316 - 318, Interview extract)

\subsection{Discussion}

This section discusses the key findings of the thesis to the relevant studies to answer two research questions.

Research Question One: What are the perceptions of doing research by tertiary EFL teachers?

\section{A. Tertiary EFL teachers' perceptions of the benefits of doing research} Firstly, regarding the benefits of professional development, the findings from questionnaires and interviews show that most teachers believed by doing research, teachers become more reflective, critical, and analytical about their teaching behaviors in the classroom. This is supported in the literature (McNiff, 2010; Goodman, 1986; Bughio, 
2015; Morales, 2016). These authors explained that when teachers actively get involved in doing research, they actively give assessments, make decisions on making changes on their pedagogies and practices and in education. This is also consistent with Beasley \& Riordan (1981) who claimed doing research benefits teachers' professional development as "it sharpens teachers' critical awareness through observation, recording and analysis of classroom events and thus acts as a consciousness-raising exercise' to the fuzzier 'it matches the subtle, organic process of classroom life". Besides, the findings indicate that doing research was perceived to help teachers update advances in teaching and learning. This echoes with the previous study of Walkins (2006) which pointed that doing research allows teachers to observe and then learn techniques in teaching practices from their colleagues to apply in their own classroom. What is more, it was found that doing research provides practical implications in teaching. This finding from the questionnaire contradicts Crookes (1993) who claimed that in language teachers' perceptions, most research articles are not directly related to immediate classroom situations and needs. The findings from interviews also reveal that teachers could accumulate knowledge, professional theories and new ideas about teaching methodologies and learners from research articles to improve their teaching. The finding is supported by a study of Hine (2013) suggesting that doing research leads to the improvement of teachers' teaching skills and their students' learning.

Finally, it was found that there was a positive correlation between years of experience and teachers' perceptions of doing research. The data show that teachers with greater experience in teaching English language perceived the benefits of research implementation at a higher level than those with less experience. This finding contradicts a previous study (Borg, 2007) confirming that experience was not considered as a significant factor affecting teachers' engagement in research.

\section{B. Tertiary EFL teachers' perceptions of the challenges of doing research}

Firstly, regarding students and colleagues' collaboration, the findings from the questionnaire show that teachers did not perceive students and colleagues' collaboration as a challenge preventing them from doing research. This finding is not consistent with a previous study (Barkhuizen, 2009) which claimed that students are not willing to participate in their research. One participant in his research stated that students "were unwilling to collaborate with me" and "dishonest in writing their true feelings".

Secondly, with respect to teachers' awareness and skills, the findings from the questionnaire and interviews show that teachers did not perceive research engagement as experts or researchers' duty. This finding is not in line with a previous study (David, 2002) who concluded that one of the research challenges relies on teachers' beliefs since most teachers did not consider doing research as a way to improve teaching and learning as well as resolve educational problems but researchers' responsibility. Besides, the findings from the questionnaire reveal that teachers did not think they have limited skills in the area of doing research which deters them from doing research.

Thirdly, with regard to resources, it was indicated from the questionnaire and interview findings that teachers acknowledged lack of time as a hindrance of engaging 
in research. This finding is supported in the literature (e.g., Borg, 2007, 2009; Brocato \& Mavis, 2005; Gao, 2006; Grbich, 1999; Hemmings et al., 2007; Hiep, 2006). The possible explanation based on the data about economic challenges for this finding is that teachers have second jobs to do to financially support their families. Besides, the finding is in alignment with a previous study (Othman, 2011) suggesting that plan development, implementation, data collection and analysis are very time-consuming.

Fourthly, with respect to economic issues, it was found that teachers disagreed that there were no financial incentives for teachers to do research and that there was no reward for teachers-researchers. The finding is not in line with a previous study (Vásquez, 2017) suggesting it is very hard for teachers to persuade management staff or education authorities to give the monetary support to conduct research properly. As a result, teachers have to make their decisions between two alternatives: "sacrifice their own income to do research" or ask the people in charge for needed support, which can take a lot of time. A study conducted by Fraenkel et al. (2011) shared a similar finding that teachers did not receive enough funding from their institution.

Fifthly, regarding demotivators, the findings from the questionnaire show that teachers did not hold a perception that their efforts are not recognized by their coworkers or management staff. This contradicts those of Edwards and Burns (2016) who proposed that teachers engaging in research are more recognized by other colleagues and managers in the teaching community.

Finally, in terms of leadership attributes, it was found that teachers denied that management staff do not motivate them to do research and have negative attitudes towards research. This finding is not consistent with previous studies (Tavakoli \& Howard, 2012; Pfeffer \& Sutton, 2000). To be more specific, Tavakoli and Howard describe, 'a main reason for not using or engaging with research, as the teachers argued, was the lack of institutional support they received in their day-to-day practice' (2012, p. 236).

Research Question Two: What are the practices of doing research by tertiary EFL teachers?

The findings from the questionnaire (the findings from the interview in this section was not evident enough) reveal that teachers' practices as researchers was at a high level. This finding contradicts a previous study (Borg, 2010) suggesting that teachers held negative attitudes towards doing research, so it is still a minority activity in EFL. Engaging in research was not considered feasible or even desirable activities by teachers owing to limitations of knowledge, attitudes, skills. Studies conducted by Biruk (2013) and Ulla (2018) also revealed the similar result that teachers had positive attitudes towards teachers' research, but only a few of them conduct research. Similarly, the results of a previous study (Dehghan \& Sahragard, 2015) showed that although being aware of the essence and values of action research, most of the language teachers did not apply it in their classes and perceived it as researchers' responsibility, not theirs. This finding matches those about teachers' perceptions of doing research. As illustrated above, teachers had positive attitudes towards doing research. Their perceptions of the benefits 
of doing research were at a high level, while it was found that teachers almost disagreed with the challenges listed in the previous section except for the lack of time. As Burn (1999) claimed, what they know and believe about issues related to their professional practices. These, therefore, explained the high level of their research practices.

Besides, it was found that teachers' qualification was a factor influencing teachers' research practices. Teachers with Doctorate degrees showed a very high level of research practices, while teachers with Bachelor and Master degrees were at a much lower level. A possible answer for this finding could be that teachers with Doctorate degrees mastered knowledge and skills of conducting research. This finding is consistent with previous studies claiming that TEFL academics with low qualifications (Chen, 2003) had limited research training and knowledge; therefore, they were unconfident in doing research. (Dai \& Zhang, 2004). However, this finding is not in line with a study conducted by Borg (2007) stating that qualifications did not impact the level of teachers' research engagement as much as the nature of education research that teachers experienced.

\section{Conclusion}

The current study investigated the perceptions and practices of doing research by Cantho tertiary EFL teachers. Two main findings were found in the study. Firstly, tertiary EFL teachers in Cantho held positive perceptions of conducting teacher research. Professional development was the most highly rated as a benefit of doing teacher research in the survey. Regarding teachers' perceptions of research challenges, the results revealed that it was believed that Cantho tertiary EFL teachers encountered few barriers. The frequently cited research challenges in previous studies such as limitations in research expertise, skills, awareness, lack of institutional support, financial incentives, inaccessibility to resources were not acknowledged by the teachers in this research. The only reported challenge Cantho tertiary EFL teachers faced was lack of time which was attributed to heavy workloads when managing to do the teaching job at school and extra jobs to earn more income for families. Secondly, Cantho tertiary EFL teachers' research practices were at a high level. This finding matched well with teachers' positive perceptions of conducting research. Since teachers found doing research beneficial and applicable in teaching and learning practices and they faced few research challenges, they applied it into their own classrooms for the sake of improving the quality of teaching and learning English language. Furthermore, the findings showed that there was a positive relation between teachers' research practices and their qualifications. The higher qualifications teachers had, the higher levels of their practices were. Understanding these is an important part of the broader process of attempting to resolve research challenges teachers are facing and thus to encourage teacher research engagement among EFL teachers. 


\section{Pedagogical implications}

\subsection{Pedagogical implications for teachers}

Firstly, with regard to teachers' perceptions about the benefits of doing research, it was found that teachers held positive perceptions about the great impacts doing teacher research has on their professional development. This finding indicates that doing research is perceived as a useful activity with valuable and practical implications, so it is suggested that teachers should raise their awareness of the importance and effects of conducting research. They should actively do research and apply its findings into their classroom practice in order to better the standards of their teaching and students' learning. Besides, it should be obligatory that teachers need to acknowledge their responsibility for continuing professional development to create intrinsic motivation to do research. What is more, it is recommended that teaching staff collaborate with their colleagues to gain more confidence in carrying out research.

\subsection{Pedagogical implications for staff managers}

Educational leaders should help to create intrinsic, extrinsic motivation as well as opportunities for teachers so that they become more conscious and engaged in conducting research. To increase teachers' intrinsic motivation, staff managers should hold periodic workshops or meetings for teachers to discuss and share research experience with their colleagues, educational leaders or policy makers. By doing this, teachers would have better consciousness of doing teacher research, have chances to equip more knowledge and skills in research areas and become confident in research involvement. Besides, extrinsic motivation could be strengthened by restructuring the current teacher evaluation system in which teachers are awarded for their applying research implications critically and also for introducing new classroom research projects (Gore \& Giltin, 2004). Moreover, financial support from institutional administrators could be seen as a practical step encouraging teachers to be research - engaged. Last but not least, as the results show, many teachers in the current study blamed lack of time as the main factor restraining them from doing research. In order to tackle this challenge, teachers should be freed from their time pressures since "sustained and productive research engagement is not feasible unless the time it requires is acknowledged and built into institutional systems" (Borg, 2007, p. 744). One possible solution is reducing teachers' workloads at school or cutting down on their teaching hours so that teachers can entirely focus on doing research productively.

\section{Suggestions for further research}

After considering the limitations of the study, some suggestions are put forward for further related research. It is recommended that this type of study should be conducted on a larger population and in various contexts to give a comprehensive picture of the issue under investigation. 
It is also suggested that there should be further studies investigating the perceptions and practices of doing research from two groups of EFL teachers including private and state-owned tertiary institutions to examine whether there is a difference in the perceptions and practices of these two groups.

\title{
Conflict of Interest Statement
}

The authors declare no conflicts of interests.

\begin{abstract}
About the Author(s)
Nguyen Thi Thu Uyen is an English teacher in a college in Cantho, Viet Nam. She is going to finish her MA program, majoring in Principles and Methods in English Language Education, at Can Tho University, Vietnam. She sustains interests in EFL teaching methodologies and Professional Development.

Truong Vien is an associate professor of English at the English Department, University of Foreign Languages, Hue University, Vietnam. He has taught EFL methodology courses to BA and MA - TESOL students for many years. His interests include Second Language Acquisition, Language Testing and Assessment, Professional Development, Material Development, Community Service Learning and Pragmatics.
\end{abstract}

\section{References}

Allison, D., \& Carey, J. (2007). What do university language teachers say about language Teaching Research? TESL Canada Journal, 24(2), 61. https://doi.org/10.18806/tesl.v24i2.139

Beasley, B., \& Riordan, L. (1981). The classroom teacher as researcher. English in Australia, $55,36-41$.

Biruk, H. (2013). The practice and challenges in conducting action research: the case of Sululta secondary school (thesis). Addis Ababa University.

Borg, S. (2007). English language teachers' views of research: Some insights from Switzerland. ETAS Journal, 24(2), 15-18.

Borg, S. (2007). Research engagement in English language teaching. Teaching and Teacher Education, 23(5), 731-747. https://doi.org/10.1016/j.tate.2006.03.012

Borg, S. (2007). Teacher research: What exactly are we talking about? One Stop English.

Borg, S. (2007). Understanding what teachers think about research. The Teacher Trainer, 21(2), 2-4.

Borg, S. (2009). English language teachers' conceptions of research. Applied Linguistics, 30(3), 358-388. https://doi.org/10.1093/applin/amp007

Borg, S. (2010). Language teacher research engagement. Language Teaching, 43(4), 391-429. https://doi.org/10.1017/s0261444810000170

Borg, S. (2014). Teacher research for professional development. In G. Pickering \& P. Gunashekar (Eds.), Innovation in English language teacher education (pp.23-28). 
Selected papers from the fourth International Teacher Educator Conference, Hyderabad, India.

Borg, W., \& Gall, M. (2007). Educational research: An introduction (8th ed.). Longman.

Brindley, G. (1991). Becoming a researcher: Teacher-conducted research and professional growth. In E. Sadtono (Ed.), Issues in language teacher education (pp. 89-105). Regional Language Centre.

Brocato, J. J., \& Mavis, B. (2005). The research productivity of faculty in family medicine departments at U.S. MEDICAL Schools: A national study. Academic Medicine, 80(3), 244-252. https://doi.org/10.1097/00001888-200503000-00008

Brown, J. D. (1988). Understanding research in second language Learning: A teacher's guide to statistics and research design. Cambridge University Press.

Bughio, F. A. (2015). Issues and Challenges in Doing Action Research in a Public Sector University. Journal of Research in Social Sciences, 3(1), 86-95.

Burns, A. (1999). Collaborative action research for English language teachers. Cambridge University Press.

Burns, A. (2010). Doing action research in English language teaching a guide for practitioners. Routledge.

Cain, T., \& Milovic, S. (2010). Action research as a tool of professional development of advisers and teachers in Croatia. European Journal of Teacher Education, 33(1), 1930. https://doi.org/10.1080/02619760903457768

Carr, W., \& Kemmis, S. (1988). Becoming critical: Education, knowledge and action research. Routledge/Falmer.

Chen, G. (2003). The challenges college English teachers are faced with and the countermeasures thereof. Foreign Language World, 1, 48-53.

Chen, Y., Gupta, A., \& Hoshower, L. (2006). Factors That Motivate Business Faculty to Conduct Research: An Expectancy Theory Analysis. Journal of Education for Business, 81(4), 179-189. https://doi.org/10.3200/joeb.81.4.179-189

Cochran-Smith, M., \& Lytle, S. L. (1999). The teacher Research movement: A decade later. Educational Researcher, 28(7), 15-25. https://doi.org/10.3102/0013189x028007015

Crookes, G. (1993). Action research for second language teachers: going beyond teacher research. Applied Linguistics, 14(2), 44-130.

Dai, M., \& Zhang, X. (2004). An investigation of English teacher qualities in colleges and universities. Journal of PLA University of Foreign Languages, 27(2).

David, M. (2002). Problems of participation: The limits of action research. International Journal of Social Research Methodology , 5(1), 11-17.

Dehghan, F., \& Sahragard, R. (2015). Iranian EFL teachers' views on action research and its application in their classrooms: A case study. Journal of Teacher Education and Educators, 41(1), 39-52.

Dörnyei, Z. (2007). Research methods in applied linguistics: Quantitative, qualitative, and mixed methodologies. Oxford University Press.

Edwards, E., \& Burns, A. (2016). Language teacher action research: Achieving sustainability. ELT Journal, 70(1), 6-15. https://doi.org/doi:10.1093/elt/ccv060 
Elliott, J., \& Sarland, C. (1995). A study of 'teachers as researchers' in the context of awardbearing courses and research degrees. British Educational Research Journal, 21(3), 371-386. https://doi.org/10.1080/0141192950210309

Ellis, N., \& Loughland, T. (2016). The challenges of Practitioner research: A comparative study of Singapore and NSW. The Australian Journal of Teacher Education, 41(2), 122136. https://doi.org/10.14221/ajte.2016v41n2.8

Everton, T., \& Galton, M. (2004). Supervisor, collaborator or critical friend: The changing roles of university tutors in teacher research. Teacher Development, 8(2-3), 241-261. https://doi.org/10.1080/13664530400200219

Everton, T., Galton, M., \& Pell, T. (2000). Teachers' perspectives on educational research: Knowledge and context. Journal of Education for Teaching, 26(2), 167-182.

Francis, S., Hirsch, S., \& Rowland, E. (1994). Improving school culture through study groups. Journal of Staff Development, 13, 12-15.

Goodman, J. (1986). Teaching preservice teachers a critical approach to curriculum design: A descriptive account. Curriculum Inquiry, 16(2), 179. https://doi.org/10.2307/1179769

Gore, J. M., \& Gitlin, A. D. (2004). [RE]Visioning the academic-teacher divide: Power and knowledge in the educational community. Teachers and Teaching, 10(1), 35-58.

Goswami, D., \& Stillman, P. (1987). Reclaiming the classroom: Teacher research as an agency for change. Boynton/Cook.

Grbich, C. F. (1998). The academic researcher: Socialisation in settings previously dominated by teaching. Kluwer.

Grima-Farrell, C. (2017). What matters in a research to practice cycle? Teachers as researchers. Springer Singapore.

Gurney, M. (1989). Implementor or innovator? A teacher's challenge to the restrictive paradigm. Multilingual Matters.

Hammersley, M. (2000). Taking Sides in Social Research: Essays on Partisanship and Bias. Psychology Press.

Hammersley, M. (2002). Research and Practice, two worlds for ever at Odds? (written with Roger Gomm). Educational Research, Policymaking and Practice, 59-82. https://doi.org/10.4135/9781849209083.n3

Hargreaves, D. H. (1996). Teaching as a research-based profession: Possibilities and prospects. Teacher Training Agency.

Hargreaves, D. H. (2001). Revitalising educational Research: Lessons from the past and proposals for the future. Cambridge Journal of Education, 29(2), 239-249. https://doi.org/10.1080/0305764990290207

Hemmings, B. C., Rushbrook, P., \& Smith, E. (2007). Academics' views on publishing refereed works: A content analysis. Higher Education, 54(2), 307-332. https://doi.org/10.1007/s10734-005-8608-x

Henson, R. K. (2001). The effects of participation in teacher research on teacher efficacy. Teaching and Teacher Education, 17(7), 819-836. https://doi.org/10.1016/s0742$\underline{051 x(01) 00033-6}$ 
Hiep, P. H. (2006). Researching the Research Culture in English Language Education in Vietnam.

Hine, G. (2013). The importance of action research in teacher education programs. Issues in Educational Research, 23(2), 151-163.

Hong, C. E., \& Lawrence, S. A. (2011). Action research in teacher education: Classroom inquiry, reflection, and data-driven decision making. Journal of Inquiry $\mathcal{E}$ Action in Education, 4(2), 1-17.

Jungck, S. (2001). How does it matter? Teacher inquiry in the traditions of social science research. In G. Burnaford, J. Fischer, \& D. Hobson (eds.), Teachers doing research: The power of action research inquiry (pp. 329-344). Mahwah, NJ: Erlbaum.

Kelchtermans, G. (2011). Vulnerability in teaching: The moral and political roots of a structured condition. In C. Day \& J.C-K. Lee (Eds.), New understandings of teacher's work: Emotions and educational change (pp. 65-82). New York: Springer.

Kemmis, S. \& R. McTaggart (eds.) (1988). The action research planner (3rd edn.). Deakin University Press.

Kincheloe, J. L. (2003). Teachers as researchers: Qualitative inquiry as a path to empowerment. Routledge.

Kirkwood, M., \& Christie, D. (2006). The role of teacher research in continuing professional development. British Journal of Educational Studies, 54(4), 429-448. https://doi.org/10.1111/j.1467-8527.2006.00355.x

Kumaravadivelu, B. (2001). Toward a postmethod pedagogy. TESOL Quarterly, 35(4), 537. https://doi.org/10.2307/3588427

Kumaravadivelu, B. (2006). TESOL methods: Changing tracks, challenging trends. TESOL Quarterly, 40(1), 59-81.

Kutlay, N. (2013). A survey of English language teachers' views of research. Procedia Social and Behavioral Sciences, 70, 188-206. https://doi.org/10.1016/j.sbspro.2013.01.055

Lankshear, C., \& Knobel, M. (2004). A handbook for teacher research from design to implementation. Open University Press.

Markee, N. (1997). Second language ACQUISITION research: A resource for Changing Teachers' Professional cultures? The Modern Language Journal, 81(1), 80-93. https://doi.org/10.1111/j.1540-4781.1997.tb01628.x

Mcdonough, K. (2006). Action research and the professional development of graduate teaching assistants. The Modern Language Journal, 90(1), 33-47. https://doi.org/10.1111/j.1540-4781.2006.00383.x

McNiff, J. (2010). Action research for professional development: Concise advice for new (and experienced) action researchers. September Books.

Morales, M. P. (2015). Participatory action Research (PAR) cum action Research (AR) in teacher professional development: A literature review. International Journal of Research in Education and Science, 2(1), 156. https://doi.org/10.21890/ijres.01395

Norasmah, O., \& Chia, S. Y. (2016). The challenges of action research implementation in Malaysian schools. Pertanika Journal of Social Science and Humanities, 24(1), 43-52. 
Nunan, D. (1997). Developing Standards for Teacher-Research in TESOL. TESOL Quarterly, 31(2), 365. https://doi.org/10.2307/3588053

Olson, M. W. (1990). The teacher as researcher: A historical perspective. In M. W. Olson (Ed.), Opening the door to classroom research (pp. 1-20). Newark, DE: International Reading Association

Othman, N. (2011). Problem-based learning in the English language classroom. English Language Teaching, 6(3).

Pfeffer, J., \& Sutton, R. I. (2000). The knowing-doing gap: How smart companies turn knowledge into action. Harvard Business School Press.

Rahimi, M., \& Weisi, H. (2018). The impact of research practice on professional teaching practice: Exploring efl teachers' perception. Cogent Education, 5(1), 1480340. https://doi.org/10.1080/2331186x.2018.1480340

Richards, J. C., \& Renandya, W. A. (2002). Methodology in language teaching: An anthology of current practice. Cambridge University Press.

Robinson, V. (1993). Problem-based methodology: Research for the improvement of practice. Emerald.

Rose, R. (2002). Research section: Teaching as a 'research-based profession': Encouraging practitioner research in special education. British Journal of Special Education, 29(1), 44-48. https://doi.org/10.1111/1467-8527.00236

Sachs, G. T. (2000). Teacher and researcher autonomy in action research. Prospect, 15(3), $35-51$.

Seliger, H. W., \& Shohamy, E. (1989). Second language research methods. Oxford University Press.

Shehadeh, A., Levis, J., \& Barkhuizen, G. (2009). Topics, aims, and constraints in English teacher research: A Chinese case study. TESOL Quarterly, 43(1), 113-125. https://doi.org/10.1002/j.1545-7249.2009.tb00231.x

Shkedi, A. (1998). Teachers' attitudes towards research: A challenge for qualitative researchers. International Journal of Qualitative Studies in Education, 11(4), 559-577. https://doi.org/10.1080/095183998236467

Stenhouse, L. (1975). An Introduction to Curriculum Research and Development. Pearson Education. https://books.google.com.vn/books?id=LQsNAQAAIAAI

Stenhouse, L. (1981). What counts as research? British Journal of Educational Studies, 29(2), 103-114. https://doi.org/10.1080/00071005.1981.9973589

Stenhouse, L. (1983). Authority, education and emancipation: A collection of papers. Heinemann Educational.

Tavakoli, P., \& Howard, M. J. (2012). Teaching English to speakers of other Languages teachers' views on the relationship between research and practice. European Journal of Teacher Education, 35(2), 229-242. https://doi.org/10.1080/02619768.2011.643398

Troudi, S., \& Riley, S. (1996). Action research: Using your classroom for professional development. Paper Presented at the 30th Annual Meeting of the Teachers of English to Speakers of Other Languages. 
Ulla, M. B. (2016). Pre-service teacher training programs in the Philippines: The Studentteachers Practicum teaching experience. EFL Journal, 1(3). https://doi.org/10.21462/eflj.v1i3.23

Ulla, M. B. (2018). Benefits and challenges of doing research: Experiences from Philippine public school teachers. Issues in Educational Research, 28(3), 797-810.

Vásquez, V. E. L. (2017). Teachers as researchers: Advantages, disadvantages and challenges for teachers intending to engage in research activities. https://doi.org/https://www.academia.edu/719736

Watkins, A. (2006). So what exactly do teacher-researchers think about doing research? Support for Learning, 21(1), 12-18. https://doi.org/10.1111/j.1467-9604.2006.00394.x

$\mathrm{Xu}$, Y. (2013). Becoming researchers: A Narrative study of Chinese university EFL Teachers' research practice and their professional Identity construction. Language Teaching Research, 18(2), 242-259. https://doi.org/10.1177/1362168813505943

Yang, Z., Zhang, Z., \& Xie, J. (2001). An analysis of the research status quo and problems of the college English teachers. Foreign Language Education, 22, 79-83.

Zhou, J. (2012). Problems teachers face when doing action research and finding possible solutions. Chinese Education $\mathcal{E}$ Society, 45(4), 68-80. https://doi.org/10.2753/ced1061-1932450405. 

to copy, distribute, transmit or adapt the article content, providing a proper, prominent and unambiguous attribution to the authors in a manner that makes clear that the materials are being reused under permission of a Creative Commons License. Views, opinions, and conclusions expressed in this research article are views, opinions, and conclusions of the author(s). Open Access Publishing Group and European Journal of Foreign Language Teaching shall not be responsible or answerable for any loss, damage, or liability caused in relation to/arising out of conflicts of interest, copyright violations, and inappropriate or inaccurate use of any kind content related or integrated into the research work. All the published works are meeting the Open Access Publishing requirements and can be freely accessed, shared, modified, distributed, and used in educational, commercial, and non-commercial purposes under a Creative Commons Attribution 4.0 International License (CC BY 4.0). 